Steric and Polar Factors Affecting Heteroring Opening of 2-[2-carboxy3,4,5,6-tetrachloro]phenyl-4H-3,1-Benzoxazin-4-one by Nitrogen and

\title{
Carbon Nucleophiles
}

\section{M.A.El- Hshash ${ }^{a}$ and J.M.Morsy ${ }^{* b}$}

${ }^{a}$ Department of Chemistry, Faculty of Science, Ain Shams University, Abbasiya 11566, Cairo, Egypt.

${ }^{b}$ Laboratory of Synthetic Organic Chemistry, Chemistry Department, Faculty of Education, 11711 Roxy, Cairo, Egypt.

Corresponding author: morsy_jehan@yahoo.com

\section{ABSTRACT}

The behavior of 2-[2-carboxy-3,4,5,6-tetrachloro]phenyl-4H-3,1-Benzoxazin-4- one towards Nitrogen nucleophiles and Carbon nucleophiles under Friedel-Crafts' reaction conditions has been investigated and steric versus polar factors affecting ring opening has been studied.

\section{INDEXING TERMS / KEYWORDS}

Benzoxazinone; steric and polar factors; nitrogen and carbon nucleophiles.

\section{Council for Innovative Research}

Peer Review Research Publishing System

Journal: Journal of Advances in Chemistry

Vol. 5, No. 2

editor@cirworld.com

www.cirworld.com, member.cirworld.com 


\section{INTRODUCTION}

4H-3,1-Benzoxazin-4-ones have been known for more than a century [1] and showed interesting pharmacological properties. For example, they are potent inactivators of chemotrypsin [2] as well as inhibitors of HSV-1 protease [3] and good selective anticancer agents [4].This class of compounds also has different kinds of pharmaceutical, agricultural and industrial applications [5-8]. They showed strong and highly specific inhibition of human sputum elastase (HSE) which is equivalent to human leukocyte elastase (HLE). Some 7-substitutedamino-5-methyl-2-isoprpylamino-4H-3,1-benzoxazin-4ones are useful therapeutic agents for the treatment of HLE-mediated diseases [9]. A series of 4H-3,1-benzoxazin-4-ones has been reportd that inhibit the serine proteases human cathepsin $\mathrm{G}$ and bovine chymotrypsin.They act as acyl-enzyme inhibitors of both enzymes [10].

Since the phenyl derivatives were first synthesized in 1883 [11], numerous 2-substituted-4H-3,1-benzoxazin-4ones have been prepared. However, substituents at the C-2 position were usually the common alkyl, alkenyl or aryl groups. The synthesis of 2 - polychloroaryl substituted $4 \mathrm{H}-3,1$-benzoxazin-4-ones has been comperatively less studied. In the present article, we report a convenient synthesis of 2- [2-carboxy-3,4,5,6-tetrachloro] phenyl-4H-3,1-benzoxazin-4one 1 from the interaction of tetrachlorophthalic anhydride with anthranilic acid and comparing its reactivity towards nitrogen and carbon nucleophiles with other 2- substituted benzoxazinone derivatives.

\section{EXPERIMENTAL}

\section{General procedure}

All melting points were measured on a Gallenkamp electric melting point apparatus and are uncorrected. The elemental analyses were carried out at the Micro analytical Center of Cairo University. All the newly synthesized compounds gave satisfactory elemental analyses. The infrared spectra were recorded using potassium bromide disks on a FTIR 8201 PC Shimadzu (Japan 1995) and ${ }^{1} \mathrm{H}$ NMR experiments were run at $300 \mathrm{MHz}$ on a Varian Mercury VX-300 NMR spectrometer using tetramethylsilane (TMS) as internal standard in deuterated dimethyl sulphoxide ( DMSO- $\mathrm{d}_{6}$ ). Chemical shifts are quoted as $\delta$. The progress of all reactions and the purity of all synthesized compounds were checked by TLC.

\section{2-[2-carboxy-3,4,5,6-tetrachloro]phenyl-4H-3,1-benzoxazin-4-one (1)}

A solution of tetrachlorophthalic anhydride $(10 \mathrm{mmol})$ and anthranilic acid $(10 \mathrm{mmol})$ in $\mathrm{n}$-butanol $(10 \mathrm{~mL}) \mathrm{was}$ heated under reflux for $5 \mathrm{~h}$. The solid that separated down from the reaction mixture after concentration and cooling was filtered off and recystallized.

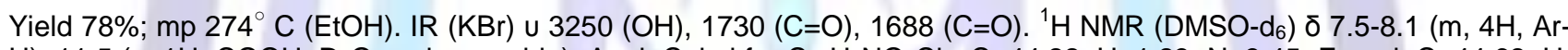
$\mathrm{H}), 11.5\left(\mathrm{~s}, 1 \mathrm{H}, \mathrm{COOH}, \mathrm{D}_{2} \mathrm{O}\right.$ exchangeable). Anal. Calcd for $\mathrm{C}_{15} \mathrm{H}_{5} \mathrm{NO}_{4} \mathrm{Cl}_{4}$ : C, 44.22; $\mathrm{H}, 1.23 ; \mathrm{N}, 3.45$. Found: $\mathrm{C}, 44.62 ; \mathrm{H}$, $1.33 ; \mathrm{N}, 3.65$

\section{2-[4H-3,1-benzoxazin-4-one-2-yl]-3,4,5,6-tetrachlorobenzoic acid hydrazide (2)}

An equimolar mixture of benzoxazinone 1 and hydrazine hydrate $(10 \mathrm{mmol})$ in $30 \mathrm{~mL}$ of ethanol was heated under reflux for $4 \mathrm{~h}$. The solid which separated after distilling off the excess solvent and cooling was filtered off and recrystallized.

Yield 72\%; mp $294^{\circ} \mathrm{C}$ (n-butanol). IR ( $\left.\mathrm{KBr}\right)$ u 3431 and 3351 ( $\mathrm{NH}$ non- bonded and bonded), $1724(\mathrm{C}=\mathrm{O}), 1640(\mathrm{C}=\mathrm{O})$, $1602(\mathrm{C}=\mathrm{N})$. ${ }^{1} \mathrm{H}$ NMR (DMSO-d $\left.\mathrm{d}_{6}\right) \delta 3.5\left(\mathrm{~s}, 2 \mathrm{H}, \mathrm{NH}_{2}, \mathrm{D}_{2} \mathrm{O}\right.$ exchangeable), 7.5-8.1 (m, 4H, Ar-H), 8.5 (s, $1 \mathrm{H}, \mathrm{NH}, \mathrm{D}_{2} \mathrm{O}$ exchangeable). ). Anal. Calcd for $\mathrm{C}_{15} \mathrm{H}_{7} \mathrm{~N}_{3} \mathrm{O}_{3} \mathrm{Cl}_{4}$ : C, 42.22; $\mathrm{H}, 1.67 ; \mathrm{N}, 10.01$. Found: $\mathrm{C}, 42.57 ; \mathrm{H}, 1.69 ; \mathrm{N}, 10.39$.

\section{2-[2(benzaldehyde and/or 4-chlorobenzaldehyde hydrazinocarbonyl)-3,4,5,6-tetrachloro]phenyl-4-H3,1-} benzoxazinones ( $3 a$ and $3 b)$

A solution of hydrazide $2(10 \mathrm{mmol})$ and an aromatic aldehyde namely, benzaldehyde and/or 4chlorobenzaldehyde $(10 \mathrm{mmol})$ in $\mathrm{n}$-butanol $(30 \mathrm{~mL})$ was heated under reflux for $4 \mathrm{~h}$ in presence of few drops of piperidine as a basic catalyst. The solid that was formed after cooling was collected by suction, washed with cold ethanol and dried to give $\mathbf{3 a}$ and/or $\mathbf{3 b}$.

3a: Yield 75\%; mp 190 $\mathrm{C}$ (n-butanol). IR (KBr) u $3350(\mathrm{NH}), 1734(\mathrm{C}=\mathrm{O}), 1614(\mathrm{C}=\mathrm{N}) .{ }^{1} \mathrm{H}$ NMR (DMSO-d $) \delta 6.5(\mathrm{~s}, 1 \mathrm{H}$, azomethine-H), 7.4-8.2 (m, $9 \mathrm{H}, \mathrm{Ar}-\mathrm{H}), 8.4\left(\mathrm{~s}, 1 \mathrm{H}, \mathrm{NH}, \mathrm{D}_{2} \mathrm{O}\right.$ exchangeable). ). Anal. Calcd for $\mathrm{C}_{22} \mathrm{H}_{11} \mathrm{~N}_{3} \mathrm{O}_{3} \mathrm{Cl}_{4}: \mathrm{C}_{5}, 52.37 ; \mathrm{H}$, 2.10; N, 8.48. Found: C, 52.57; H, 1.89; N, 8.27.

3b: Yield 73\%; mp $210^{\circ} \mathrm{C}$ (n-butanol). IR (KBr) u $3355(\mathrm{NH}), 1725(\mathrm{C}=\mathrm{O}), 1600(\mathrm{C}=\mathrm{N}) .{ }^{1} \mathrm{H}$ NMR (DMSO-d 6 ) $\delta 6.6$ (s, $1 \mathrm{H}$, azomethine-H), 7.7-8.3 (m ,8H, Ar-H), $8.5\left(\mathrm{~s}, 1 \mathrm{H}, \mathrm{NH}, \mathrm{D}_{2} \mathrm{O}\right.$ exchangeable). ). Anal. Calcd for $\mathrm{C}_{22} \mathrm{H}_{10} \mathrm{~N}_{3} \mathrm{O}_{3} \mathrm{Cl}_{5}: \mathrm{C}_{4} 48.57 ; \mathrm{H}$, 1.84 ; N, 7.75.Found: $\mathrm{C}, 48.41 ; \mathrm{H}, 1.71 ; \mathrm{N}, 7.68$.

\section{2-[2(3-methyl-5-oxo-pyrazolin-1-ylcarbonyl)3,4,5,6-tetrachloro]phenyl-4H-3,1-benzoxazin-4-one (4)}

A solution of hydrazide $2(10 \mathrm{mmol})$ and ethyl acetoacetate $(10 \mathrm{mmol})$ in dimethyl formamide $(20 \mathrm{~mL})$ was heated at boiling point under reflux for $6 \mathrm{~h}$. The reaction mixture was diluted by cold water. The solid product which settled down was collected by suction filtration and recrystallized to afford compound 4.

Yield 67\%; over $300{ }^{\circ} \mathrm{C}$ (acetic acid). IR (KBr) u 3236, $3200(\mathrm{NH}), 1797,1746,1680(\mathrm{C}=\mathrm{O}) .{ }^{1} \mathrm{H}$ NMR $\left(\mathrm{DMSO}-\mathrm{d}_{6}\right) \delta 1.8(\mathrm{~s}$, $\left.3 \mathrm{H}, \mathrm{CH}_{3}\right), 2.5\left(\mathrm{~s}, 1 \mathrm{H}, \mathrm{NH}, \mathrm{D}_{2} \mathrm{O}\right.$ exchangeable), $4.8\left(\mathrm{~s}, 1 \mathrm{H}, \mathrm{OH}, \mathrm{D}_{2} \mathrm{O}\right.$ exchangeable $), 5.1(\mathrm{~s}, 1 \mathrm{H}$, pyrazolone moiety $\mathrm{H})$ and 7.5-8.1 (m, 4H, Ar-H). Anal. Calcd for $\mathrm{C}_{19} \mathrm{H}_{9} \mathrm{~N}_{3} \mathrm{O}_{4} \mathrm{Cl}_{4}$ : C, 47.01; $\mathrm{H}, 1.85 ; \mathrm{N}$, 8.65.Found: $\mathrm{C}, 67.00 ; \mathrm{H}, 1.90 ; \mathrm{N}, 8.71$. 
2-[2-chloroacetyl-hydrazinocarbonyl-3,4,4,6-tetrachloro]phenyl-4H-3,1-benzoxazin-4-one (5)

An equimolar mixture of hydrazide 2 and ethyl chloroacetate $(10 \mathrm{mmol})$ in $20 \mathrm{~mL}$ of DMF was heated under reflux for $5 \mathrm{~h}$. The reaction mixture was left to cool and diluted with water. The solid which deposited was filtered off and recrystallized to yield product $\mathbf{5}$

Yield 71\%; mp $182^{\circ} \mathrm{C}$ (ethanol). IR (KBr) u $3220(\mathrm{NH}), 1734,1695,1692(\mathrm{C}=\mathrm{O}) .{ }^{1} \mathrm{H}$ NMR (DMSO-d 6 ) $\delta$ at $\delta 4.88(\mathrm{~s}, 2 \mathrm{H}$, methylene protons of chloroacetyl moiety ), 7.82, 7.83 ( two s, $4 \mathrm{H}, \mathrm{ArH}$ ), 11.34 ( $\mathrm{S}, 2 \mathrm{H}, \mathrm{NH}, \mathrm{D}_{2} \mathrm{O}$ exchangeable ). Anal. Calcd for $\mathrm{C}_{17} \mathrm{H}_{8} \mathrm{~N}_{3} \mathrm{O}_{4} \mathrm{Cl}_{5}$ : C, 41.17; $\mathrm{H}, 1.61 ; \mathrm{N}, 8.47$.Found: $\mathrm{C}, 40.93 ; \mathrm{H}, 1.50 ; \mathrm{N}, 8.40$.

\section{N-Benzylbenzamide 6}

A solution of compound $5(10 \mathrm{mmol})$ and benzyamine $(20 \mathrm{mmol})$ in $20 \mathrm{~mL}$ of ethanol was heated at boiling temperature under reflux for $5 \mathrm{~h}$. Concentrating followed by cooling of the reaction mixture afforded a crude solid product which was collected by filtration and recrystallized to give product 6.

Yield 65\%; mp $225^{\circ} \mathrm{C}$ (n-butanol). IR (KBr) u 3440 and 3280 ( $\mathrm{NH}$ non-bonded and bonded), 1647(C=O). ${ }^{1} \mathrm{H}$ NMR (DMSO$\left.\mathrm{d}_{6}\right) \delta 2.3\left(\mathrm{~s}, 1 \mathrm{H}\right.$, broad $\mathrm{NH}$ of amine moiety, $\mathrm{D}_{2} \mathrm{O}$ exchangeable), $3.51\left(\mathrm{~s}, 2 \mathrm{H}, \mathrm{CH}_{2}\right.$ of amide moiety), $3.97\left(\mathrm{~s}, 2 \mathrm{H}, \mathrm{CH}_{2}\right.$ of benzyl moiety), 7.10-8.00 (m, $9 \mathrm{H}, \mathrm{Ar}-\mathrm{H}), 8.4$ (s, $2 \mathrm{H}, \mathrm{NH}, \mathrm{D}_{2} \mathrm{O}$ exchangeable). Anal. Calcd for $\mathrm{C}_{31} \mathrm{H}_{25} \mathrm{~N}_{5} \mathrm{O}_{4} \mathrm{Cl}_{4}: \mathrm{C}, 55.27 ; \mathrm{H}$, $3.71 ; \mathrm{N}, 10.37$. Found: C, 55.33; H, 3.74; N, 10.42 .

\section{2-[2-(4-phenyl-1,2,4-triazolo-5-thione-3-yl)-3,4,5,6-tetrachloro]phenyl-4H-3,1-benzoxazin-4-one (7)}

A solution of hydrazide $2(10 \mathrm{mmol})$ and phenyl isothiocyanate $(10 \mathrm{mmol})$ in $10 \mathrm{~mL}$ of DMF was heated at boiling temperature under reflux for $6 \mathrm{~h}$. The reaction mixture was left to cool and diluted with water. The solid which separated out was filtered off and recrystallized to yield product 7.

Yield $65 \%$; over $300^{\circ} \mathrm{C}$ (dimethyl formamide). IR $(\mathrm{KBr})$ u $3207(\mathrm{NH}), 1723(\mathrm{C}=\mathrm{O}), 1343(\mathrm{C}=\mathrm{S}) .{ }^{1} \mathrm{H}$ NMR $\left(\mathrm{DMSO}-\mathrm{d}_{6}\right) \delta 6.5$ (s, $1 \mathrm{H}, \mathrm{NH}, \mathrm{D}_{2} \mathrm{O}$ exchangeable), 6.9-8.0 (m, $\left.9 \mathrm{H}, \mathrm{Ar}-\mathrm{H}\right)$. Anal. Calcd for $\mathrm{C}_{22} \mathrm{H}_{10} \mathrm{~N}_{4} \mathrm{O}_{2} \mathrm{Cl}_{4} \mathrm{~S}: \mathrm{C}, 49.25 ; \mathrm{H}, 1.86 ; \mathrm{N}$, 10.44.Found: C, 49.13; $\mathrm{H}, 1.91 ; \mathrm{N}, 10.52$.

\section{1-(2-(2,3,4,5-tetrachloro-6-(4-phenyl-5-thioxo-4,5-dihydro-1H-1,2,4-triazol-3-yl)benzamido)benzoyl)urea (8)}

A solution of compound $7(10 \mathrm{mmol})$ and urea $(10 \mathrm{mmol})$ in dioxan $(20 \mathrm{~mL})$ was heated under reflux for $4 \mathrm{~h}$. The solid that separated out from the reaction mixture after dilution with water was filtered off and recrystallized to afford compound 8.

Yield $66 \% ; 135^{\circ} \mathrm{C}$ (dioxan). IR ( $\left.\mathrm{KBr}\right)$ u 3350 and 3466 (bonded and non-bonded NH), 1684, 1635 and $1630(\mathrm{C}=\mathrm{O}) .{ }^{1} \mathrm{H}$ NMR (DMSO- $\left.\mathrm{d}_{6}\right) \delta 6.1\left(\mathrm{~s}, 2 \mathrm{H}, \mathrm{NH}_{2}, \mathrm{D}_{2} \mathrm{O}\right.$ exchangeable), $6.4\left(\mathrm{~s}, 1 \mathrm{H}, \mathrm{NH}\right.$ of pyrazoline moiety, $\mathrm{D}_{2} \mathrm{O}$ exchangeable), 6.7-7.9 (m, $9 \mathrm{H}, \mathrm{Ar}-\mathrm{H}), 8.1$ (broad s, NH of anilide, $\mathrm{D}_{2} \mathrm{O}$ exchangeable), $11.0\left(\mathrm{~s}, 1 \mathrm{H}\right.$, imide $\mathrm{NH}, \mathrm{D}_{2} \mathrm{O}$ exchangeable). Anal. Calcd for $\mathrm{C}_{23} \mathrm{H}_{14} \mathrm{~N}_{6} \mathrm{O}_{3} \mathrm{Cl}_{4} \mathrm{~S}: \mathrm{C}, 46.15 ; \mathrm{H}, 2.34 ; \mathrm{N}, 14.04$. Found: $\mathrm{C}, 46.21 ; \mathrm{H}, 2.70 ; \mathrm{N}, 14.21$.

\section{Bridgehead nitrogen 9}

A mixture of equimolar amounts of benzoxazinone 1 and o-phenylenediamine $(10 \mathrm{mmol})$ was fused in an oil bath at $170^{\circ} \mathrm{C}$ for $3 \mathrm{~h}$ and the reaction mixture was diluted with water. The solid obtained was filtered off, washed by cold water, dried and recrystallized to give compound 9.

Yield $70 \%$; over $300^{\circ} \mathrm{C}$ (acetic acid). IR (KBr) u $3468(\mathrm{OH}), 1708(\mathrm{C}=\mathrm{O}), 1661(\mathrm{C}=\mathrm{N}) .{ }^{1} \mathrm{H}$ NMR $\left(\mathrm{DMSO}-\mathrm{d}_{6}\right) \delta 7.3,7.6,8.1$ and $8.8(4 \mathrm{~d}, 8 \mathrm{Ar}-\mathrm{H}), 12.6\left(\mathrm{~s}, 1 \mathrm{H}, \mathrm{COOH}, \mathrm{D}_{2} \mathrm{O}\right.$ exchangeable). Anal. Calcd for $\mathrm{C}_{21} \mathrm{H}_{9} \mathrm{~N}_{3} \mathrm{O}_{2} \mathrm{Cl} l_{4}: \mathrm{C}, 52.60 ; \mathrm{H}, 1.87 ; \mathrm{N}$, 8.76. Found: C, $52.72 ; \mathrm{H}, 1.92 ; \mathrm{N}, 8.86$.

\section{4-(2-(4,5,6,7-tetrachloro-3-oxoisobenzofuran-1(3H)-ylideneamino)benzamido) benzoic acid (10)}

A solution of benzoxazinone $1(10 \mathrm{mmol})$ and 4-aminobenzoic acid $(10 \mathrm{mmol})$ in ehanol $(20 \mathrm{~mL})$ was heated under reflux for $5 \mathrm{~h}$. The solid that separated out during reflux was filtered off and recrystallized to afford product 10.

Yield $60 \%$; over $300^{\circ} \mathrm{C}$ (acetic acid). IR (KBr) u $3230(\mathrm{NH}), 1775(\mathrm{C}=\mathrm{O}), 1670(\mathrm{C}=\mathrm{O}), 1607(\mathrm{C}=\mathrm{N}) .{ }^{1} \mathrm{H}$ NMR $\left(\mathrm{DMSO}-\mathrm{d}_{6}\right) \delta$ 7.2, 7.4, 8.2 and $8.3(4 \mathrm{~d}, 8 \mathrm{Ar}-\mathrm{H}), 9.50\left(\mathrm{~s}, 1 \mathrm{H}, \mathrm{NH}, \mathrm{D}_{2} \mathrm{O}\right.$ exchangeable) $12.3\left(\mathrm{~s}, 1 \mathrm{H}, \mathrm{COOH}, \mathrm{D}_{2} \mathrm{O}\right.$ exchangeable). Anal. Calcd for $\mathrm{C}_{22} \mathrm{H}_{10} \mathrm{~N}_{2} \mathrm{O}_{5} \mathrm{Cl}_{4}$ : C, 50.18; $\mathrm{H}, 1.90 \mathrm{~N}, 5.32$. Found: $\mathrm{C}, 50.11 ; \mathrm{H}, 1.81 ; \mathrm{N}, 5.21$.

\section{4,5,6,7-tetrachloro-3-(2-(piperidine-1-carbonyl)phenylimino)isobenzofuran-1(3H)-one (11)}

A mixture of benzoxazinone $1(10 \mathrm{mmol})$ and piperidine $(10 \mathrm{mmol})$ was heated in an oil bath at $130^{\circ} \mathrm{C}$ for 2 h. The reaction mixture was triturated with cold ethanol, filtered off, dried and recrystallized to yield compound 11.

Yield $72 \% ; 240^{\circ} \mathrm{C}$ (ethanol). IR (KBr) u 1785 and $1670(\mathrm{C}=\mathrm{O}) .{ }^{1} \mathrm{H}$ NMR (DMSO- $\left.\mathrm{d}_{6}\right) \delta$ 1.90-3.80 (m, $10 \mathrm{H}$, piperidine moiety),7.2- $8.1(\mathrm{~m}, 4 \mathrm{H}, \mathrm{Ar}-\mathrm{H})$. Anal. Calcd for $\mathrm{C}_{20} \mathrm{H}_{14} \mathrm{~N}_{2} \mathrm{O}_{3} \mathrm{Cl}_{4}$ : C, 50.63; H, 2.95, N, 5.90.Found: C, 50.69; H,2.99; N, 6.63.

\section{2-[2-Carboxy-3,4,5,6-tetrachloro]phenyl-3-hydroxyquinazolin-4-one (12)}

A solution of $1(10 \mathrm{mmol})$ and hydroxylamine hydrochloride $(15 \mathrm{mmol})$ in dry pyridine $(20 \mathrm{~mL})$ is heated at boiling temperature under reflux for $3 \mathrm{~h}$. The reaction mixture was poured with stirring into crushed ice and dil. hydrochloric acid. The solid product which precipitated was filtered off and recrystallized to give quinazolinone 12. 
Yield $65 \% ; 264^{\circ} \mathrm{C}$ (glacial acetic acid). IR (KBr) u $3450(\mathrm{OH}), 1707$ and $1695(\mathrm{C}=\mathrm{O}) .{ }^{1} \mathrm{H}$ NMR (DMSO-d 6 ) $\delta 5.00(\mathrm{~s}, 1 \mathrm{H}$, $\mathrm{OH}, \mathrm{D}_{2} \mathrm{O}$ exchangeable), $11.5\left(\mathrm{~s}, 1 \mathrm{H}, \mathrm{COOH}, \mathrm{D}_{2} \mathrm{O}\right.$ exchangeable), 7.4- $7.9(\mathrm{~m}, 4 \mathrm{H}, \mathrm{Ar}-\mathrm{H})$. Anal. Calcd for $\mathrm{C}_{15} \mathrm{H}_{6} \mathrm{~N}_{2} \mathrm{O}_{4} \mathrm{Cl}_{4}$ : C, 42.65; H,1.42, N, 6.63.Found: C, 42.60; H,1.32; N, 6.50 .

\section{2-[2-Arylcarbonyl-3,4,5,6-tetrachloro]phenyl-4H-3,1-benzoxazin-4-one (13a-c)}

A mixture of benzoxazinone derivative $1(10 \mathrm{mmol})$ and dry aromatic hydrocarbon namely, ethyl benzene, $\mathrm{p}$ xylene and cumene $(30 \mathrm{~mL})$ in the presence of anhydrous aluminium chloride $(15 \mathrm{mmol})$ was heated on steam bath for 6 $\mathrm{h}$. The reaction mixture was left aside at room temperature for $24 \mathrm{~h}$., poured into crushed ice-cold dilute hydrochloric acid with stirring. The excess of aromatic hydrocarbon was removed by steam distillation. The reaction mixture was extracted by ether and the ethereal layer was dried over anhydrous sodium sulfate. The solid obtained after slow evaporation of the dried ether was collected and recrystallized.

13a: Yield $50 \% ; 138^{\circ} \mathrm{C}$ ( glacial acetic acid). IR (KBr) u 1722 and $1688(\mathrm{C}=\mathrm{O}) .{ }^{1} \mathrm{H}$ NMR (DMSO-d $) \delta 1.3(\mathrm{t}, 3 \mathrm{H},-$ $\left.\mathrm{CH}_{2} \underline{\mathrm{CH}}_{3}\right), 2.5$ (q, 2H, $-\underline{-\mathrm{CH}_{2}} \mathrm{CH}_{3}$ ), $7.1-7.9$ (m, 8H, Ar-H). Anal. Calcd for $\mathrm{C}_{23} \mathrm{H}_{13} \mathrm{NO}_{3} \mathrm{Cl}_{4}: \mathrm{C}, 55.75 ; \mathrm{H}, 2.62, \mathrm{~N}, 2.82 . F o u n d: \mathrm{C}$, $55.80 ; \mathrm{H}, 2.71 ; \mathrm{N}, 2.85$.

13b: Yield $52 \% ; 170^{\circ} \mathrm{C}$ ( dimethyl formamide). IR (KBr) u 1726 and $1690(\mathrm{C}=\mathrm{O}) .{ }^{1} \mathrm{H}$ NMR (DMSO-d 6 ) $\delta 2.3(\mathrm{~s}, 6 \mathrm{H}$, $\left.2 \mathrm{CH}_{3}\right)$, 7.0- 8.1 (m, 7H, Ar-H). Anal. Calcd for $\mathrm{C}_{23} \mathrm{H}_{13} \mathrm{NO}_{3} \mathrm{Cl}_{4}$ : C, 55.75; H,2.62, N, 2.82.Found: C, 55.12; $\mathrm{H}, 2.68 ; \mathrm{N}, 3.00$

13c: Yield $55 \% ; 140^{\circ} \mathrm{C}$ ( glacial acetic acid). IR (KBr) u 1730 and $1685(\mathrm{C}=\mathrm{O})$. ${ }^{1} \mathrm{H}$ NMR (DMSO-d $) \delta 1.3(\mathrm{~s}, 6 \mathrm{H}$, $\left.2 \mathrm{CH}_{3}\right), 3.1\left(\mathrm{~m}, 1 \mathrm{H}, \mathrm{CH}\left(\mathrm{CH}_{3}\right)_{2}\right), 7.3-7.9(\mathrm{~m}, 8 \mathrm{H}, \mathrm{Ar}-\mathrm{H})$. Anal. Calcd for $\mathrm{C}_{24} \mathrm{H}_{15} \mathrm{NO}_{3} \mathrm{Cl}_{4}: \mathrm{C}, 56.58 ; \mathrm{H}, 2.94, \mathrm{~N}, 2.75 . F o u n d: \mathrm{C}$, $56.44 ; \mathrm{H}, 3.40 ; \mathrm{N}, 3.10$.

\section{RESULTS and DISCUSSION}

When tetrachlorophthalic anhydride was allowed to react with anthranilic acid in boiling butanol, it yielded 2- [2carboxy-3,4,5,6-tetrachloro] phenyl-4H-3,1-benzoxazin-4-one 1 [cf.Scheme 1].<smiles>Nc1ccccc1C(=O)O</smiles><smiles>Ic1ccccc1</smiles><smiles></smiles><smiles>CCC(C)C</smiles>

1a (strongly H-bonded) $\mathrm{H}$-atom is between two oxygen atoms

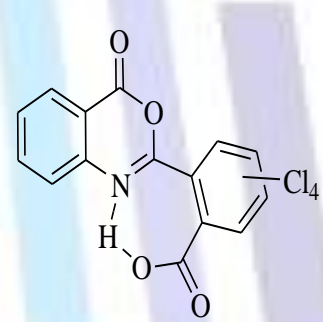

$1 \mathbf{b}$ (moderately H-bonded)

$\mathrm{H}$-atom is between

oxygen and nitrogen atoms

\section{Scheme 1}

Compound $\mathbf{1}$ is present in two conformations $\mathbf{1 a}$ and $\mathbf{1 b}$. Although conformation $\mathbf{1 b}$ is moderately $\mathrm{H}$-bonded but it seems to be more stable than 1a due to its exhibition a decrease in steric hindrance and the carboxyl group is nearly present in the same plane of oxazinone nucleus and its ability to form hydrogen bonding with nitrogen atom. The structure of compound 1 was inferred from the correct microanalytical data and its IR spectrum which shows strong absorption bands at 1688, 1730 and a basin peak centered at $3250 \mathrm{~cm}^{-1}$ attributable to $U$ max of two carbonyl groups and $U$ OH (chelated).

Recently [12,13], it has been reported that heating $4 H-3,1$-benzoxazin-4-one in neat hydrazine hydrate or in ethanol at boiling temperature under reflux produced the 3 -aminoquinazolin-4- $(3 H)$-one. Herein, the authors sought to study the behavior of 2-[2-carboxy-3,4,5,6-tetrachloro]phenyl-4H-3,1-benzoxazin-4-one 1 towards hydrazine hydrate to throw more precise information about the steric and polar factors of the group at position 2 on the heteroring opening. Thus, when compound 1 was submitted to react with hydrazine hydrate in boiling ethanol, it afforded $2-(4 \mathrm{H}-3,1-$ benzoxazin-2-yl)-3,4,5,6,-tetrachlorobenzoic acid hydrazide 2. The structure of compound 2 was established from correct microanalytical data and its IR spectrum which exhibits absorption bands at 1602, 1640, 1724, 3270, 3351 and $3431 \mathrm{~cm}^{-1}$ attributable to $\mathrm{U}_{\mathrm{C}=\mathrm{N}}, \mathrm{U}_{\mathrm{C}=\mathrm{O}}$ and $\mathrm{U}_{\mathrm{NH}}$ bonded and non-bonded.

The reaction possibly takes place through the route shown in Scheme 2. 
<smiles>NC(=O)c1cc(Cl)ccc1-c1nc2ccccc2c(=O)o1</smiles>

\section{Scheme 2}

The structural features of compound 2 were also inferred chemically from the following series of reactions:

1- When hydrazide 2 was submitted to react with aromatic aldehydes namely, 4-chlorobenzaldehydehydrazin-carbonyl)3,4,5,6-tetrachloro]phenyl-4H-3,1-benz-oxazinones $\mathbf{3 a}$ and / or $\mathbf{3} \mathbf{b}$ [cf.Scheme 3]. IR spectra of compounds 3 exhibit strong absorption bands in the region 1600-1614, 1725-1734 and $3350 \mathrm{~cm}^{-1}$ attributable to $U \mathrm{C}=\mathrm{N}, \mathrm{U} C=\mathrm{O}$ and $\mathrm{U} N H$ respectively.

2- When compound 2 was allowed to react with ethyl acetoacetate in boiling DMF (dimethyformamide), it gave pyrazolone derivative 4. IR spectrum of compound 4 showed strong absorption bands at 1680, 1746, 1797, 3200 and $3236 \mathrm{~cm}^{-1}$ attributable to $u \max$ of carbonyl groups and $u \mathrm{NH}$. The high value for stretching frequencies of carbonyl groups is due to mutual induction and field effects between oxygen and chlorine atoms. The $1 \mathrm{H}$ NMR spectrum of compound 4 exhibits the following signals $\delta 1.8\left(\mathrm{~s}, 3 \mathrm{H}, \mathrm{CH}_{3}\right), 2.5\left(\mathrm{~s}, 1 \mathrm{H}, \mathrm{NH}, \mathrm{D}_{2} \mathrm{O}\right.$ exchangeable), $4.8\left(\mathrm{~s}, 1 \mathrm{H}, \mathrm{OH}, \mathrm{D}_{2} \mathrm{O}\right.$ exchangeable), $5.1(\mathrm{~s}, 1 \mathrm{H}$, pyrazolone moiety $\mathrm{H}$ ) and $7.5-8.1(\mathrm{~m}, 4 \mathrm{H}, \mathrm{Ar}-\mathrm{H})$. Such ${ }^{1} \mathrm{H}$ NMR data illustrates that compound 4 exists in lactam-lactim dynamic equilibrium mixture $\mathbf{A}$ and $\mathbf{B}$.

3- Interaction of compound 2 with ethyl chloroacetate in boiling DMF yielded 2-[(2-chloroacetylhydrazinocarbonyl)-3,4,5,6.tetrachloro]phenyl-4H-3,1-benzoxazinone (5). The strong absorption bands observed in the IR spectrum of compound 5 at 1692, 1695, 1734 and 3220 are attributable to $U \max$ of carbonyl groups and $U \mathrm{NH}$. The ${ }^{1} \mathrm{H}$-NMR spectrum of benzoxazinone derivative 5 in DMSO- $\mathrm{d}_{6}$ exhibits signals at $\delta 4.88$ ( $\mathrm{s}, 2 \mathrm{H}$, methylene protons of chloroacetyl moiety ), 7.82, 7.83 ( two s, $4 \mathrm{H}, \mathrm{ArH}$ ), 11.34 ( $\mathrm{S}, 2 \mathrm{H}, \mathrm{NH}, \mathrm{D}_{2} \mathrm{O}$ exchangeable ). Structure of compound $\mathbf{5}$ was chemically inferred via its reaction with benzylamine in boiling $\mathrm{n}$-butanol to afford compound 6 via nucleophilic displacement of chlorine atom in chloroacetyl moiety through $\mathrm{SN}^{2}$ mechanism. IR spectrum of compound 6 revealed strong absorption bands at 1647,3280 and $3440 \mathrm{~cm}^{-1}$ attributable to $\mathrm{U}_{\mathrm{C}=\mathrm{O}}$ and $\mathrm{U}_{\mathrm{NH}}$ bonded and non-bonded respectively. 
<smiles>O=C(O)c1cccc(Cl)c1-c1nc2ccccc2c(=O)o1</smiles><smiles>N=C(N)c1ccc(Cl)cc1C(=O)NCc1ccccc1</smiles><smiles></smiles>

$\mathrm{a}, \mathrm{Ar}=\mathrm{C}_{6} \mathrm{H}_{5} ; \mathrm{b}, \mathrm{Ar}=\mathrm{C}_{6} \mathrm{H}_{4}-\mathrm{Cl}-4$<smiles>Cc1cc(O)n(CC2CCCCC2)n1</smiles><smiles>CNC(=O)c1ccccc1NC(=O)c1ccccc1C(=O)NNC(=O)CNCc1ccc(Cl)cc1</smiles>

(i) $\mathrm{NH}_{2} \mathrm{NH}_{2} \mathrm{H}_{2} \mathrm{O}$, EtOH,reflux; (ii) Ar-CHO, n-BuOH, Piperidine, reflux; (iii) $\mathrm{CH}_{3} \mathrm{COCH}_{2} \mathrm{COOC}_{2} \mathrm{H}_{5}$, DMF, reflux;

(iv) $\mathrm{ClCH}_{2} \mathrm{COOC}_{2} \mathrm{H}_{5}$, DMF, reflux; (v) $\mathrm{PhCH}_{2} \mathrm{NH}_{2}$, EtOH, reflux; (vi) PhNCS, DMF, reflux; (vii) $\mathrm{NH}_{2} \mathrm{CONH}_{2}$, Dioxane, reflux

\section{Scheme 3}

4- Phenyl isothiocyanate reacted with hydrazide 2 in boiling DMF to give 2 [2(4-phenyl-1,2,4-triazole-5-thione-3-yl)-3,4,5,6tetrachloro] phenyl-4H-3,1-benzoxazin-4-one (7).IR spectrum of compound 7 showed strong absorption bands at 1343 , 1723 and 3207 attributable to $\mathrm{U} C=\mathrm{S}, \mathrm{U} \mathrm{C}=\mathrm{O}$ and $\mathrm{U} \mathrm{N}-\mathrm{H}$ respectively. The structure of compound 7 was also chemically inferred from its reaction with urea. Thus, when compound 7 was allowed to react with urea in boiling dioxane, it yielded the triazol derivative 8. IR spectrum of triazole 8 exhibits strong absorption bands at $1630,1635,1684,3350$ and 3466 attributable to $U_{\max }$ of carbonyl groups and $\mathrm{U} \mathrm{N}-\mathrm{H}$.

Interaction of benzoxazinone derivative 1 with o-phenylenediamine by fusion in an oil bath at $170^{\circ} \mathrm{C}$ afforded the bridgehead nitrogen compound 9 [cf Scheme 4].

The structure of product 9 was established from its satisfying microanalytical, IR and ${ }^{1} \mathrm{H}-\mathrm{NMR}$ spectral data. Thus, IR spectrum of compound 9 showed strong absorption bands at 1661,1708 and 3488 attributable to $\mathrm{U}_{\mathrm{C}=\mathrm{N}}, \mathrm{U}_{\mathrm{C}=\mathrm{O}}$ and $\mathrm{U} \mathrm{O}-\mathrm{H}$ respectively. The $\mathrm{H}-\mathrm{NMR}$ spectrum of compound 9 in $\mathrm{DMSO}-\mathrm{d}_{6}$ exhibits signals at 7.32, 7.64, 8.08 and $8.75 \mathrm{ppm}(4 \mathrm{~d}, 8 \mathrm{ArH}), 12.6(\mathrm{~s}, 1 \mathrm{H}, \mathrm{COOH})$.

Compound 1 reacted with $p$-aminobenzoic acid $(\mathrm{PAB})$ in boiling dioxane to yield the furanone derivative 10 via heteroring opening followed by cyclization. The IR spectrum of compound 10 revealed strong absorption bands at 1607 , 1670,1775 and 3230 attributable to $U_{C=N}, U_{C=O}$ and $U_{N-H}$ respectively. The ${ }^{1} \mathrm{H}-\mathrm{NMR}$ spectrum of compound 10 in DMSO$\mathrm{d}_{6}$ showed signals at 7.20,7.44, 8.20, $8.33(4 \mathrm{~d}, 8 \mathrm{H}, \mathrm{ArH}), 9.50\left(\mathrm{~s}, 1 \mathrm{H}, \mathrm{NH}\right.$ exchangeable with $\left.\mathrm{D}_{2} \mathrm{O}\right)$ and $12.30(\mathrm{~s}$, $1 \mathrm{H}, \mathrm{COOH}$ exchangeable with $\left.\mathrm{D}_{2} \mathrm{O}\right)$. 


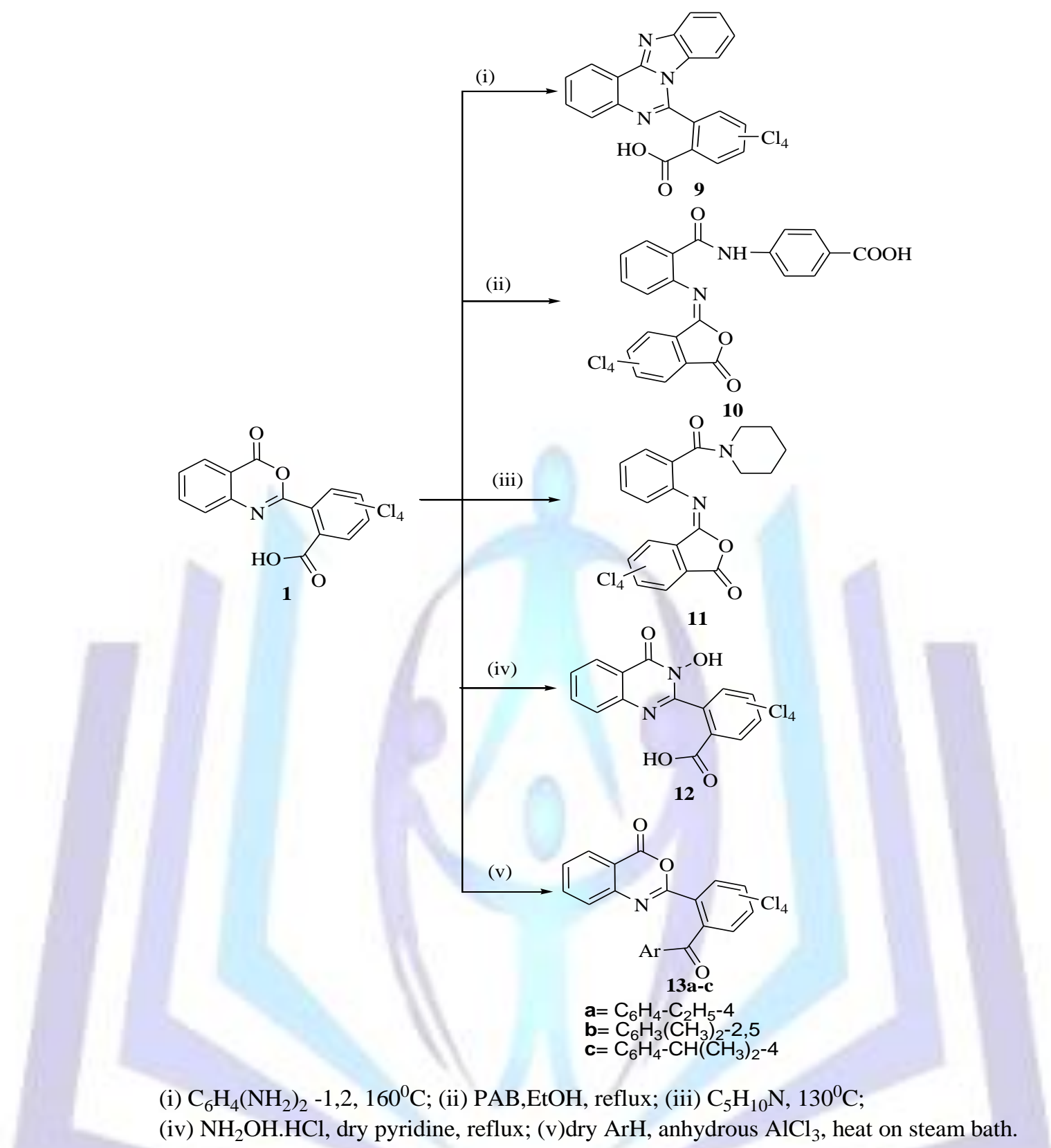

\section{Scheme 4}

Neat piperidine was reacted with benzoxazinone derivative 1 in an oil bath at $130^{\circ} \mathrm{C}$ and afforded the furanone derivative 11. IR spectrum of compound 11 exhibits strong absorption bands at 1670 and 1785 attributable to $\mathrm{U}=\mathrm{C}$ groups. . The ${ }^{1} \mathrm{H}-\mathrm{NMR}$ spectrum of compound 9 in DMSO-d6 showed signals at 2.00-4.00 (m, $10 \mathrm{H}$, piperidine moiety) and 7.00- $8.30(\mathrm{~m}, 4 \mathrm{H}, \mathrm{ArH})$.

It has been reported that $4 \mathrm{H}-3,1$-benzoxazin-4-one derivatives react with hydroxyl- amine hydrochloride in boiling dry pyridine and undergo heterocyclic opening and recyclization to give hydroxyl quinazolin-4(3H)-one [12,14], In the present work, the authors sought to investigate the behavior benzoxazinone derivative 1 towards the same reagent with the aim of obtaining more precise information about the course of reaction when position 2 bears a bulky group with strong withdrawing inductive effect (-I effect). Thus, when compound 1 was allowed to react with hydroxylamine hydrochloride in boiling dry pyridine, it afforded 2-[2-carboxy-3,4,5,6-tetrachloro]phenyl-3-hydroxy-4(3H)-quinazolin-4-one (12). The reaction takes place via heteroring opening of oxazinone nucleus at $\mathrm{C}-4$ followed by cyclization to give the isolated product. IR spectrum of compound 12 showed absorption bands at 1695, 1707 and 3450 attributable to $U$ max of two carbonyl groups and $\mathrm{U} \mathrm{OH}$ respectively.

An interesting result has been obtained when the authors studied the behavior of 2-[2-carboxy-3,4,5,6tetrachloro]phenyl-4H-3,1-benzoxazin-4-one (1) towards aromatic hydrocarbons under Friedel-Crafts reaction conditions. Thus, when compound $\mathbf{1}$ was allowed to react with aromatic hydrocarbons namely, ethylbenzene, $p$-xylene and cumene in the presence of anhydrous aluminium chloride, it gave 2-[2-aroyl-3,4,5,6-tetrachloro]phenyl-4H-3,1-benzoxazin-4-one 
(13a-c). IR spectra of compounds 13a-c exhibit strong absorption bands at the regions 1685-1690 and 1720-1730 attributable to $U_{\max }$ of two carbonyl groups. The reaction likely proceeds via the mechanism indipted in scheme 5 .<smiles>O=C(O)c1ccccc1/N=C1\OC(=O)c2cc(Cl)ccc21</smiles><smiles>O=C(O)c1ccccc1N=C(O)c1ccc(Cl)cc1C(=O)[Al]C1CCCCC1</smiles>

Scheme 5

The reaction possibly takes place via combination of $\mathrm{AlCl}_{3}$ as a Lewis acid with the ring oxygen of benzoxazinone nucleus as a basic center followed by nucleophilic attack of hydroxyl oxygen of carboxilic group to form the fleeting intermediate furanone which is attacked by aromatic hydrocarbon followed by cyclization leading to the desired benzoxazinone 13a-c.

\section{CONCLUSION}

In order to explain the static behaviour i.e, stability of benzoxazinone derivatives, we have to take into consideration both the polar and steric factors of the substituents at position 2:

The polar factor (conjugation power and $+\mathrm{l}$ effect) saturates the oxazinone nucleus by electrons and consequently renders the heteroring opening by nucleophiles so difficult. On the other hand, electron withdrawing groups lead to increase of the ability of heteroring opening by the same reagents.

(ii) The bulky substituents at position 2 hinder the approach of nucleophiles and increase stability. Herein, the (2-carboxy-3,4,5,6-tetrachloro ) phenyl moiety at position 2 is bulky and strong electron attracting substituent in which the steric and polar factors are opposing each other. The results lead us to claim that this benzoxazinone derivative seems to be stable and the steric factor displays a prominent role in the course of heteroring opening and overcomes the polar factor.

\section{REFERENCES}

1. G. M. Coppola, J. Heterocycl. Chem. 1999, 36(3), 563-588.

2. T. Teshima, J. C. Griffin, J. C. Power, J. Biol. Chem. 1982, 257(9), 5085-5091

3. R. L. Jarvest, M. J. Paratt, C. M. Debouck, J. G. Gorniak, L. J. Jennings, H. T. Serafinowska, J. E. Strickler, Bioorg. Med. Chem. Lett. 1996, 6, 2463-2466.

4. T. M. Abdel-Rahman, J. Heterocycl. Chem. 2005, 42(7), 1257-1265

5. C. Bulluci, F. Gualtieri, A. Chiarini, Eur. J. Med. Chem., 1987, 22(5), 473-477.

6. P. Jr. Wiker, A.Wilson, J. Am. Chem. Soc. 1955, 977, 5598-5601.

7. M. L. Bouillant, J. Pavre-Bonvin, P.Ricci, Tetrahedron Letters, 1983, 24(1), 51-52.

8. M. Ponchet, J.Martin-Tanguy, A. Marais, A.Poupet, Phytochem., 1981, 23(9), 1901-1903

9. Y.Uejima, M. Kokubo, J. Oshida, H. Kawabata, Y. Kato, K. Fujii, J.Parmacol. Exp. Ther. 1993, 265(2), 516-523.

10. M. Gutschow, U. Neumann, Bioorg.Med.Chem.1997, 5(10), 1935-1942.

11. P. Friedlaender, S. Wleugel, Chem. Ber.1883, 16, 2229.

12. M. A. El-Hashash, Y. A. El-Badry, Helvetica Chimica Acta, 2011, 94(3), 389-396.

13. J. M. Morsy, Bulgarian Chemical Communications 2007, 39(2), 146-151.

14. E. A. Kassab, M. A. Elhashash, F. M. A. Soliman, R. S. Ali, Egypt. J. Chem. 2001, 44, 169-179. 